NBER WORKING PAPER SERIES

\title{
INTERGENERATIONAL TRANSMISSION OF GENDER ATTITUDES: EVIDENCE FROM INDIA
}

\author{
Diva Dhar \\ Tarun Jain \\ Seema Jayachandran \\ Working Paper 21429 \\ http://www.nber.org/papers/w21429
NATIONAL BUREAU OF ECONOMIC RESEARCH
1050 Massachusetts Avenue
Cambridge, MA 02138
July 2015

The paper has benefitted from detailed comments from Shilpa Aggarwal, Sisir Debnath, Sonalde Desai, Ravinder Kaur, E. Somanathan and Rohini Somanathan and helpful feedback from seminar and conference audiences. We thank Suanna Oh, Lydia Kim, Alejandro Favela, Vrinda Kapur, Niki Shrestha, Rachna Nag Chowdhuri, Anantika Singh and Priyanka Sarda for excellent research assistance. We are also grateful to the International Initiative for Impact Evaluation and the International Growth Centre for funding the data collection. Jayachandran is also grateful for financial support from the National Science Foundation. The views expressed herein are those of the authors and do not necessarily reflect the views of the National Bureau of Economic Research.

NBER working papers are circulated for discussion and comment purposes. They have not been peerreviewed or been subject to the review by the NBER Board of Directors that accompanies official NBER publications.

(C) 2015 by Diva Dhar, Tarun Jain, and Seema Jayachandran. All rights reserved. Short sections of text, not to exceed two paragraphs, may be quoted without explicit permission provided that full credit, including (C) notice, is given to the source. 
Intergenerational Transmission of Gender Attitudes: Evidence from India

Diva Dhar, Tarun Jain, and Seema Jayachandran

NBER Working Paper No. 21429

July 2015

JEL No. J16,O1

\section{ABSTRACT}

This paper examines the intergenerational transmission of gender attitudes in India, a setting where discrimination against women and girls is severe. We use survey data on gender attitudes (specifically, views about the appropriate roles and rights of women and girls) collected from adolescents attending 314 schools in the state of Haryana, and their parents. We find that when a parent holds a more discriminatory attitude, his or her child is about 15 to 20 percentage points more likely to hold the view. As a benchmark, classmates' average gender attitudes have a similar effect size. We find that mothers influence children's gender attitudes more than fathers do. Parental attitudes also affect their children's aspirations; girls with more discriminatory parents are less likely to want to continue their schooling beyond high school.

Diva Dhar

Indian Statistical Institute

divadhar@gmail.com

Seema Jayachandran

Tarun Jain

Indian School of Business

Department of Economics

Northwestern University

Gachibowli

2001 Sheridan Road

Hyderabad, India 500032

Evanston, IL 60208

tj9d@virginia.edu

and NBER

seema@northwestern.edu 


\section{Introduction}

Along many different dimensions - from life expectancy to educational attainment to decisionmaking power in the household - gender gaps favoring men are larger in poorer countries (Jayachandran 2015). Data on stated attitudes about gender equality follow the same pattern, with people in poorer countries more likely to endorse girls getting less education than boys and believing that violence against women is sometimes justified. Even against this backdrop, India stands out for its unequal opportunities and outcomes for women. The economic consequences of gender discrimination are potentially large, including poorer human capital accumulation in the next generation, although pursuing equality for its own sake is also an important policy objective (Duflo 2012).

One explanation for India's exceptionalism is that its religious and cultural institutions give families economic incentives to have fewer girls and to invest less in them. For example, under the system of patrilocal exogamy, girls join their husbands' family when they marry, while eldest sons provide for their parents and inherit the family land, providing incentives for parents to favor sons (Deininger, Goyal, and Nagarajan 2013; Jain 2014).

However, economic rationales seem unable to fully explain the level of gender discrimination in India. Investments in girls' health and education ought to have financial returns for parents in the form of lower dowry payments. Yet, dowry levels in most communities have not fallen despite major advances in women's educational achievement. This suggests that in addition to incentives, preferences might be systematically different in India. A preference-based explanation might explain, for example, why Indians compared to other poor countries are more likely to agree that a university education is more important for a boy compared to a girl (Jayachandran 2015). Insofar as these preferences are deeply held and difficult to change through pro-girl policies such as financial incentives to have daughters and to educate them, they may represent a significant challenge to erasing discrimination against women. At the same time, understanding the process of attitude formation and transmission offers the possibility that reforming basic gender-equality atti- 
tudes can produce long-lasting improvements in outcomes for women. Attitude formation among adolescents is particularly important to understand, since they are still at an age where attitudes are malleable, and could be reformed with targeted policy interventions.

Where do these preferences, or gender attitudes, come from? One line of research emphasizes the deep historical roots of gender attitudes. For example, they might be influenced by religious doctrine (Psacharopoulos and Tzannatos 1989; Seguino 2011) as well as by the agricultural environment faced by the first settled farming communities (Alesina, Giuliano, and Nunn 2013). Other work, mostly in the context of developed countries such as the United States and Australia, has focused on the shorter-run transmission of attitudes from one generation to another; parents' gender attitudes and behaviors have a significant impact on their children's fertility choices, household division of labor between men and women, and women's participation in the labor market (Fernandez, Fogli, and Olivetti 2004; Fernandez and Fogli 2006; Grosjean and Khattar 2014).

Relatively little research examines the formation of gender attitudes in developing countries in general, or in India specifically. Two notable exceptions are Beaman et al. (2009)'s study of attitudes associated with female leadership of village councils in India, and Jensen and Oster (2009)'s research on the impact of television on household female empowerment. We add to this literature by examining the intergenerational transmission of gender attitudes in India. The parentchild correlation of gender attitudes might differ in the social context of South Asia for a number of reasons. For example, intergenerational transmission might be especially strong in South Asia because of residence in large joint families and parents' control over when and whom their children marry. The endogamous caste system also means that people interact within a social network that holds relatively un-diversified attitudes.

Besides studying an important setting, we also advance the literature by using direct measures of gender attitudes collected simultaneously from children and their parents and by using a rich set of variables to control for many other contextual factors. This allows us to improve on the causal identification found in many other papers on intergenerational transmission (though our ability to establish causality is by no means perfect). Specifically, our sample comprises children from 314 
schools in the Indian state of Haryana, plus their parents, and we examine the correlation between children's and parents' attitudes, controlling for school fixed effects, as well as several household variables that might be correlated with parental attitudes. The survey measured a wide range of gender attitudes regarding, for example, education, working outside the home, and tolerance of violence.

Our main finding is that parent and child attitudes are strongly positively correlated, with mothers having greater influence than fathers. On average, when a parent holds a more discriminatory gender attitude, his or her child is 15 percentage points more likely to hold that attitude. The effect for mothers is $50 \%$ larger than the effect for fathers. There is also some suggestive evidence of an interactive effect with mothers having relatively more influence on their daughters than on their sons, and fathers having little influence on daughters. To address measurement error, we also instrument for one gender attitude variable with the remaining variables, and, with this correction, the effect size is about 23 percentage points. These results point to the durability - but not complete persistence - of gender attitudes over generations.

To benchmark the magnitude of these effect sizes, we also construct the average gender index of the child's peers, specifically classmates in the same school, grade, and of the same gender, excluding herself or himself. Increasing a parent's attitudes by a unit has the same effect as increasing each of the child's peers by one unit; thus a parent is more influential than a peer, but collectively peers - or the broader classroom environment - also exhibit strong influence on a child's gender attitudes.

We also examine whether parental gender attitudes have consequences for their children's and specifically girls' aspirations. We find that girls with more gender-discriminatory parents intend to drop out of school earlier than those with more gender-progressive parents. This result indicates that parental attitudes not only influence child attitudes but also their likely long-term welfare. 


\section{Data}

\subsection{Sampling and data collection}

We use data from a survey conducted between September 2013 and January 2014, covering 314 government secondary schools located in Rohtak, Sonepat, Panipat and Jhajjar districts of Haryana. Adjacent to Delhi, these districts have some of the most male-skewed sex ratios in the country. We conducted in-school surveys of roughly 15,000 students who were in grades six and seven at the time. For a $40 \%$ random sample of these students, we visited the household to survey one of the parents, randomly choosing either the mother or the father.

The survey was the first wave of a student-level panel dataset designed to evaluate a schoolbased intervention (that aims to reduce students' gender discriminatory attitudes through biweekly classroom discussions about gender equality). Decisions about sample size and school and respondent selection, among other considerations, were made based on the design of that evaluation to reduce sample attrition from the panel and ensure sufficient power to evaluate the intervention. From among the 607 government run secondary schools that offered grades six through nine in the study districts, we focused on 347 schools with low dropoff in enrollment between grades (as a proxy for attrition from the school) and medium to high enrollment, based on District Information System for Education (DISE) 2011 data. In villages with multiple schools, only one school per village was randomly selected. ${ }^{1}$ We made initial visits to these 347 schools and then narrowed the list to 314 schools; we excluded the other 33 because of chronically low actual attendance, despite high official enrollment. The 314 schools form the sample used in this study. Of these, 59 schools enroll only girls and 40 schools enroll only boys, with the remaining 215 schools enrolling both boys and girls. Each school has an average of 84 students per grade. ${ }^{2}$

\footnotetext{
${ }^{1}$ If these schools were adjacent to each other or shared a building, we considered them a single school.

${ }^{2}$ The sampling procedure implies that the schools included in the study deviate from the universe of schools in a number of ways. First, our survey does not cover the 731 private unaided schools which are disproportionately in urban areas; thus, urban and wealthier students are underrepresented. Second, among government schools, we excluded schools where grades six and seven had a combined average enrollment of less than 45 students; the government schools in our sample have higher enrollment and are in larger villages than the universe of government schools.
} 
To select students within schools for the sample, we randomly chose among those whose parents gave informed consent for their child to participate in the study and who personally agreed to participate, stratifying by gender and grade in the ratio Female 6th:Male 6th:Female 7th:Male 7th of 3:2:2:2. We surveyed more girls than boys because female enrollment is higher than male enrollment in government schools, as discussed below. We sampled more grade 6 girls than grade 7 girls because we expect lower attrition among them during our follow-up survey waves. An additional criterion was that the student attended school on the survey day. Students with chronically low school attendance or whose parents were opposed to the survey are under-represented in the data (though the consent rate was not lower for girls, suggesting that providing consent was not systematically related to parental gender attitudes).

Boys are more likely to attend private schools than are girls. At the same time, wealthier families send their children to private schools, so if every family is more likely to send their sons than daughters to private schools, the boys in government schools will be from relatively poorer families than the girls. When making comparisons between boys and girls, we correct for this differential selection into our sample by household wealth for boys versus girls (on average, higher household wealth is associated with more progressive gender attitudes in our sample).

One parent of a random $40 \%$ subsample of the surveyed students participated in a household survey. ${ }^{3}$ We selected at random whether to interview the father or the mother. If after multiple visits and follow-up phone calls, we could not interview the selected parent, we randomly chose a replacement household. The completion rate of the household survey was higher for mothers (89.6\%) than for fathers $(70.2 \%)$ because fathers were more often away for work during the daytime hours when the survey was conducted. Our final dataset consists of 2439 boys and 3044 girls, and 2379 fathers and 3104 mothers, corresponding to 5483 parent-child pairs.

\footnotetext{
${ }^{3}$ Budget constraints were the reason why only $40 \%$ of parents were chosen.
} 


\subsection{Descriptive statistics}

Table 1 summarizes some key variables for the sample. The average age for both boys and girls is between 11 and 12 years. The mean age is 35 years for mothers and 40 years for fathers. What is striking is the difference in illiteracy between mothers (39.0\%) and fathers (16.4\%), reflecting large differences in school enrollment between boys and girls in the previous generation.

The table also reports differences in the number of other children in the household, with girls growing up in larger households than boys, consistent with son-biased fertility stopping rules. Girls' siblings are also more likely to be boys, a pattern that likely reflects sex-selective abortions by their parents.

Because of selection into government versus private schools, boys in government schools are from systematically poorer families. Thus despite girls growing up in larger families, the boys in our sample are more likely to have illiterate parents and are less likely to have a flush toilet at home.

The survey included a number of questions on gender equity attitudes answered by both students and parents, covering topics such as gender roles within the household and in public life and whether girls and boys should have equal educational opportunities. We create a gender index that aggregates the responses for the nine questions listed in Table 2, which are the overlapping questions on the parent and student questionnaire. Surveyed parents and students were asked if they agree with these nine statements. An indicator variable equals one if the respondent answered "Agree" or "Strongly agree" (zero if "Disagree" or "Strongly disagree") if the statement was in favor of (opposed to) gender equality and female empowerment. The gender index is the average value of the nine dummies, so ranges from 0 to 1 . A higher gender index means more gender equitable views. The standard deviation of this variable is about 0.2 for both students and parent. To test robustness of our results, we also construct a second gender index that, instead of simply averaging the variables, normalizes them to have the same standard deviation and then uses a weighted average, with the weights given by the inverse covariance matrix (Anderson 2008).

The bottom of Table 2 shows the average gender index for girls, boys, mothers and fathers. 
Fathers and mothers are relatively close to each other, with fathers slightly more gender equitable. However, among the adolescents, girls are considerably more gender equitable than boys their age. Figure 1 shows the full distribution of the gender index variable, with girls' gender index shifted to the right of boys', while mothers' distribution shifted slightly to the left (less progressive) compared to fathers and much to the left compared to girls. These summary statistics are suggestive that girls' attitudes might become less progressive over time, but we cannot conclude this definitively because the patterns could reflect cohort effects rather than age effects.

Appendix Table 1, columns 1 and 2, summarize the gender differences in attitudes in a regression framework. The lower gender index (less progressive views) of mothers compared to fathers is statistically significant but small in magnitude (less than 0.1 standard deviation). Girls have more progressive attitudes than boys, and the difference is about 0.6 standard deviations.

\section{Empirical strategy}

\subsection{Average effect of parental attitudes on child attitudes}

The goal of the empirical analysis is to measure the strength of the intergenerational transmission of gender attitudes from parents to children. Our main specification to measure the average relationship is as follows:

$$
\text { ChildGA }_{\text {igcsd }}=\alpha_{1} \text { Parent }_{\text {Pigcsd }}+\gamma_{s}+\delta_{g c d}+\sigma X_{i g c s d}+\epsilon_{\text {igcsd }}
$$

The outcome ChildGA is the gender attitude index for student $i$ of gender $g$ in class (i.e., grade) $c$ in school $s$ in district $d$. The standard errors allow for non-independence (i.e., clustering) of the error term, $\epsilon_{i g c s d}$, by school-grade-gender.

The key regressor is the gender attitude index of the surveyed parent, ParentGA. One concern in interpreting $\alpha_{1}$ as a causal effect is that ParentGA might be correlated with gender attitudes in the community. To control for community attitudes, we include school (i.e., village) fixed effects, $\gamma_{s}$. Thus, the comparisons are between students in the same school. Girls and boys might be 
affected differently by community attitudes, so we also include district-grade-gender fixed effects, $\delta_{g c d}$; these also control for grade-specific characteristics that are common across schools in the district such as the school curriculum. Finally we include an extensive set of household covariates, $X_{i g c s d}$. These variables include whether the house is "pukka", has a toilet, electricity and piped water; father's educational level, mother's educational level, father's work status, Scheduled Caste, Scheduled Tribe, radio ownership, television ownership, and others. ${ }^{4}$

We also estimate versions of equation (1) using the weighted gender index, using an ordered logit model, and using child educational aspirations as the outcome.

It is important to acknowledge that definitively identifying the causal effect of parent attitudes on children is difficult. Shared environmental characteristics might influence both parent and child attitudes and vary even within a village (for example, by neighborhood). Our extensive set of household control variables, and the fact that our point estimates are stable when we add additional control variables (as shown below) is suggestive that most of the shared environmental factors are being addressed.

Another concern is that the direction of causality could run from children to parents rather than from parents to children. Econometrically, we have no solution to this problem, but we would argue that it is more plausible that parents are influencing the views of their 11 to 12 year old children than vice versa. Reverse causality seems especially unlikely to explain our finding that when parents have more gender-discriminatory attitudes, girls but not boys have lower educational aspirations.

\subsection{Heterogeneity by parent and child gender}

Examining heterogeneity in the effects helps to determine the pathways through which transmission occurs. First, we examine heterogeneity by the parent's gender by including the main effect Mother and the interaction term Mother $\times$ ParentGA in equation (1). A positive coefficient

\footnotetext{
${ }^{4}$ The results are also robust to including school-gender-grade fixed effects. The reason our main specification does not include school-gender-grade fixed effects is that we also include peer gender attitudes in Table 3 , and this variable only varies at the school-gender-grade analysis.
} 
on the interaction term implies that mothers are more influential than fathers.

Second, we examine heterogeneity by student gender by including the main effect Girl and the interaction term Girl $\times$ ParentGA. A positive coefficient on the interaction terms means that girls are more influenced by their parents than boys are.

Because of wealth difference for the two genders in our sample due to selection into government schools, one concern is that the gender differences are really measuring household wealth differences. To address this, we calculate the propensity score to be a boy by running a probit regression of being a boy on a large set of household measures of socioeconomic status. ${ }^{5}$ This propensity score variable serves as a proxy for household wealth and all other characteristics that vary between the boys and girls in our sample. Appendix Table 1 illustrates this. In column 3, we regress student gender attitudes on Girl but exclude the household controls. Compared to when we include them (column 2), we estimate a more positive coefficient because the coefficient now reflects both the more progressive attitudes of adolescent girls compared to their male classmates and the higher wealth of their families. In column 4, when we include the propensity score, it has a negative association with attitudes, consistent with attitudes being more progressive in wealthier families and boys in our sample being from less wealthy families. Moreover, the coefficient on Girl becomes smaller as this source of omitted variable bias is removed. Importantly, columns 2 and 4 give the same coefficient on Girl - where column 2 controls for each individual household characteristics separately and column 4 has a univariate control variable that combines the characteristics into one propensity score. The propensity score is capturing the richness of the household wealth variables in a parsimonious but comprehensive way.

Thus, to correct for selection into the sample, whenever we include an interaction of child gender with parental gender attitudes, we will also control for the interaction of the propensity

\footnotetext{
5 The explanatory variables in the propensity score calculation are the same ones in the "extended household controls" that we include in our main specifications (student-reported: mother/father is illiterate, finished primary school, finished secondary school, father works part-time, father works full-time, house is pukka, house has electricity, house has a flush toilet, house has a non-flush toilet, HH has tap water, family owns house, household gets newspaper daily; parent-reported: scheduled caste, scheduled tribe, HH owns radio, TV, water pump, HH gets newspaper daily). The variable is demeaned and missing values are replaced with the sample mean and flags for missing values are included in the propensity score regression.
} 
score and parental attitudes. ${ }^{6}$ The specification to measure heterogeneity by child gender is as follows, with interactions with Girl and parallel interactions with PropBoy (the propensity score to be a boy):

$$
\begin{aligned}
\text { ChildGA }_{i g c d s}= & \alpha_{1} \text { ParentGA }_{i g c s d}+\alpha_{2} \text { ParentGA }_{i g c s d} \times \text { Girl }_{\text {igcsd }}+\beta_{1} \text { ParentGA }_{i g c s d} \times \text { PropBoy }_{i g c s d} \\
& +\beta_{2} \text { PropBoy }_{i g c s d}+\gamma_{s}+\delta_{g c d}+\sigma X_{i g c s d}+\epsilon_{i g c d s}
\end{aligned}
$$

Note that the main effect of Girl is absorbed by the district-grade-gender fixed effects.

We also examine whether there are same-gender effects with mothers being relatively more influential with girls and fathers with boys:

$$
\begin{aligned}
\text { ChildGA }_{\text {igcds }}= & \alpha_{1} \text { ParentGA }_{\text {igcsd }}+\alpha_{2} \text { ParentGA }_{\text {igcsd }} \times \text { Girl }_{\text {igcsd }}+\alpha_{3} \text { ParentGA }_{\text {igcsd }} \times \text { Mother }_{\text {igcsd }} \\
& +\alpha_{4} \text { ParentGA }_{\text {igcsd }} \times \text { Mother }_{i g c s d} \times \text { Girl }_{i g c s d}+\delta_{1} \text { Mother }_{i g c s d} \times \text { Girl }_{i g c s d} \\
& +\delta_{2} \text { Mother }_{i g c s d}+\text { PropBoy }_{\text {igcsd }} \cdot \beta+\gamma_{s}+\delta_{g c d}+\sigma X_{i g c s d}+\epsilon_{i g c s d}
\end{aligned}
$$

In this specification, $\alpha_{4}$ represents the differential impact of mothers' attitudes on girls (relative to their effect on boys or relative to the impact of fathers on girls). PropBoy in this case is a vector of the parallel variables to those that include irl $^{7}$

\footnotetext{
${ }^{6} \mathrm{~A}$ similar concern could pertain to the comparison of mothers and fathers due to the fathers' lower survey response rate and the selection into being home and available for the survey. Constructing a propensity score to be surveyed based on work status, flexibility of hours, household wealth, ownership of a cellphone (for scheduling the survey) and several other variables, we find that for both mothers and fathers, the propensity to be surveyed has no correlation with gender attitudes (results available upon request). Thus to keep the specifications more parsimonious, we do not regression-adjust for selection into the parent sample by gender, though doing so has no appreciable effect on the coefficients (results available upon request).

${ }^{7}$ PropBoy includes PropBoy, PropBoy $\times$ ParentGA, PropBoy $\times$ ParentGA $\times$ Mother, and PropBoy $\times$ Mother.
} 


\section{Results}

\subsection{Main results on the intergenerational transmission of gender attitudes}

Table 3 presents results on the intergenerational transmission of gender-equity attitudes. Column 1 shows the unadjusted univariate relationship between the child and parent gender indices. We then successively add control variables. Column 2 includes school and district-grade-gender fixed effects, and column 3 adds in household covariates, specifically whether the house is pukka, has electricity, has a flush toilet, has a non-flush toilet; whether the family owns the house; whether the father and mother are illiterate, have finished primary school, and have finished middle school; and whether the family belongs to a scheduled caste and a scheduled tribe. The effect size of 0.15 implies that when a parent holds a more gender equitable view, his or her child is 15 percentage points more likely to hold that view.

Column 4 then adds additional controls such as whether the household has radio, television, and tap water. The coefficient on parental gender attitudes remains stable, which is suggestive that our set of control variables is capturing the environmental factors that jointly affect parents' and childrens' gender attitudes. This specification with "extended household controls" is our preferred specification for the remainder of the paper.

Column 5 adds additional control variables that could affect children's gender attitudes but are also potentially endogenous because they are affected by the parents' gender attitudes: mother's work status, family size, and the gender composition of children in the household. The patterns are robust to including these additional variables, in any case. Because we regard these extra variables as overcontrolling, we use the specification in column 4 as our main specification.

Appendix Table 2 shows the main specification separately for each of the nine questions used to create the index. Students' attitudes are positively correlated with parent's attitudes for all cases, and statistically significant in most cases. The only insignificant coefficient is in response to "Girls should be allowed to study as far as they want", where there is very little variation in responses for either students or their parents. 
One concern in interpreting the effect sizes reported in Table 3 is that, because parental gender attitudes are measured with error, the OLS coefficients could be biased. To help address measurement error, Appendix Table 3 presents instrumental variables (IV) regressions, question by question, in which the eight other parental attitude variables (eight instruments) are used to predict the parent's attitude for a particular question. (The first stage results are reported in Appendix Table 4.) Our nine gender attitude variables are not based on re-asking the identical question, so an important caveat is that this is not a standard case of IV to correct measurement error in which we have multiple measures of the exact same variable. The premise of our IV approach is that an individual has an underlying level of gender discrimination, and each of our attitude questions is a different measure of his or her discrimination. With this IV approach, we find effect sizes that are larger in magnitude than using OLS (comparing the results in Appendix Table 3 to those in Appendix Table 2. On average for the nine attitude measures, the IV estimates correcting for measurement error indicate that when a parent holds a more discriminatory view, his or her child is 22.5 percentage points more likely to hold it; this effect size is about 50 percent larger than the OLS results.

Peers and the classroom environment might also influence adolescents' gender attitudes. As a way of gauging whether the effect of parents' attitudes is large or small, in the final column of Table 3 we augment the specification in equation (1) with a measure of the average gender attitudes in the child's peer group. We define the peer group as the same-gender students in the same grade in the school. The peer set is parsed by gender because most interaction is de facto gender segregated, even in co-ed schools. Because the estimates control for school fixed effects, the estimate of peer effects holds the school environment fixed, but there might be omitted classlevel factors (e.g., teachers, textbooks). Thus, we interpret these coefficients as representing the effect of the classroom environment, including peer effects, rather than the pure effect of other students. As seen in column 6, a unit increase in classmates' average gender index is associated with a 0.13 unit increase in a student's gender index, while the coefficient on the parent's attitude is 0.15 . Peers do matter, but the collective effect of all peers (plus the classroom environment) is slightly smaller than the effect of the student's parent. 


\subsection{Heterogeneity by parent and child gender}

In Table 4, we examine heterogeneity by the parent's and child's gender. Column 1 reproduces our main specification, column 4 of Table 3 . In column 2, we find that mothers' attitudes are more influential than fathers' attitudes. The interaction coefficient of 0.063 compared to the main effect of 0.112 implies that the effect of mothers' attitudes is 55\% larger than the effect of fathers' attitudes.

Column 3 includes interactions with child gender. We find a smaller effect of parent attitudes on girls. However, unlike the heterogeneity by parent gender, this pattern is only marginally significant, and not robust when we vary the specification, as shown below. Thus, while the point estimates are suggestive of smaller effects for girls, we consider the evidence tenuous.

Finally, in column 4, we include the triple interaction of ParentGA, Mother, and Girl in order to separately estimate the mother-daughter, mother-son, father-daughter, and father-son correlations. We find that fathers have less influence on their daughters than on their sons' attitudes. The point estimates also suggest that mothers have greater influence on their daughters than on their sons, although the coefficient is not statistically significant. These patterns corroborate responses during focus group discussions with students that were conducted in 15 schools. In these discussions, $75 \%$ of girls and $54 \%$ of boys reported that the mother was the largest source of influence. In contrast, $17 \%$ of girls and $32 \%$ of boys said their father is the most important influence.

Appendix Table 5 considers alternative specifications. The first four columns reproduce Table 4 using an optimally weighted average of the nine gender attitude questions instead of a simple average. We find the same patterns of mothers having more influence than fathers, but the result that girls are less influenced by their parents, especially by their fathers, is not robust to this change in specification. Columns 5 to 8 show that findings are qualitatively similar using an ordered logit rather than linear specification. 


\subsection{Effects on educational aspirations}

We next examine whether parental gender attitudes affect intended behavior. Columns 1 to 3 in Table 5 examine whether parents' gender attitudes affect the desire to continue school beyond high school (grade 12). We find a strong positive relationship between the parent gender index and girls' plans for education $(0.167, p<0.05$ in column 2). Gender-progressive parents appear to create an environment where girls aspire to higher education. The fact that parental gender attitudes affect girls' but not boys' educational aspirations is reassuring about the econometric specification, as this specific pattern is more difficult (but of course not impossible) to explain with reverse causality or omitted variable bias.

In column 3, focusing on girls, we find suggestive evidence that their fathers' attitudes have more influence on their aspirations. This pattern contrasts with the earlier result that mothers influence children's attitudes more. Speculatively, this difference could be due to fathers having more decision-making power in the family. A daughter's aspirations might reflect both her preferences, which her mother especially influences, and what she views as possible for her to achieve. Her father's gender-discriminatory attitudes might constrain her choices because of his influence in the family, thus dampening her aspirations.

In columns 4 to 6 , we examine similar specifications for whether children discuss their educational goals with their parents. Here we find some weak evidence that parental attitudes affect this behavior as well; parents with discriminatory attitudes are less likely to talk to their daughters, but not sons, about educational goals.

\section{Conclusion}

This paper examines the intergenerational transmission of attitudes toward gender equality in the context of a developing country, and specifically one with especially large gender gaps in outcomes. Using survey data that directly and simultaneously measured these attitudes among school children and their parents in rural India, we find that child attitudes are strongly influenced 
by parents' attitudes, especially mothers'. We also show that there is a strong correlation between parent gender attitudes and girls' educational aspirations, underlining the critical role of attitudes on long term welfare.

Our findings should be read with a few caveats. First, we do not address selection into school attendance, and both the degree of gender-discriminatory attitudes and their intergenerational transmission might be very different in the (small minority of) families that hold especially conservative views and do not allow their children, especially girls, to study through grade six. A related issue is that just because we uncovered evidence of intergenerational transmission of gender-equality attitudes in this setting does not imply that these findings can be readily generalized to all contexts. Participants in our study in rural Haryana, which has one of the worst child sex ratios in India, might simultaneously hold conservative gender views and be particularly motivated to transmit those views to their children. Alternatively, the parents in our setting might have attitudes so far out of step with the messages that their children are hearing on television and elsewhere that their children emulate their views less in this context than others.

Second, while we examine the effect of parent attitudes on a number of proximate outcomes, the cross-sectional nature of the data source does not allow us to estimate the impact of parent attitudes on long term child welfare measures such as years of schooling, occupational choice, marriage and fertility. The role of parent attitudes might be mitigated once children are older, are financially independent, and do not live with their parents.

Nonetheless, the findings suggest the importance of policies that address gender equality attitudes among both parents and children as an important pathway to improve women's outcomes. 


\section{References}

Alesina, A., P. Giuliano, and N. Nunn (2013). On the origins of gender roles: Women and the plough. Quarterly Journal of Economics 128(2), 469-530.

Anderson, M. (2008). Multiple inference and gender differences in the effects of early intervention: A reevaluation of the Abecedarian, Perry preschool, and early training projects. Journal of the American Statistical Association 103(484), 1481-1495.

Beaman, L., R. Chattopadhyay, E. Duflo, R. Pande, and P. Topalova (2009). Powerful women: Does exposure reduce bias? Quarterly Journal of Economics 124(4), 1497-1540.

Deininger, K., A. Goyal, and H. Nagarajan (2013). Women's inheritance rights and intergenerational transmission of resources in India. Journal of Human Resources 48(1), 114-141.

Duflo, E. (2012). Women empowerment and economic development. Journal of Economic Literature 50(4), 1051-1079.

Fernandez, R. and A. Fogli (2006). Fertility: The role of culture and family experience. Journal of European Economic Association 4(2-3), 552-561.

Fernandez, R., A. Fogli, and C. Olivetti (2004). Mothers and sons: Preference formation and female labor force dynamics. Quarterly Journal of Economics 119(4), 1249-1299.

Grosjean, P. and R. Khattar (2014). It's raining men! Hallelujah? Australian School of Business Research Paper No. 2014 ECON 29.

Jain, T. (2014). Where there is a will: Fertility behavior and sex bias in large families. Journal of Human Resources 49(2), 393-423.

Jayachandran, S. (2015). The root causes of gender inequality in developing countries. Annual Review of Economics forthcoming.

Jensen, R. and E. Oster (2009). The power of TV: Cable television and women's status in India. Quarterly Journal of Economics 124(3), 1057-1094.

Psacharopoulos, G. and Z. Tzannatos (1989). Female labor force participation: An international perspective. World Bank Research Observer 4(2), 187-201.

Seguino, S. (2011). Help or hindrance? Religion's impact on gender inequality in attitudes and outcomes. World Development 39(8), 1308 - 1321. 
Figure 1: Distribution of gender index for female versus male students and parents
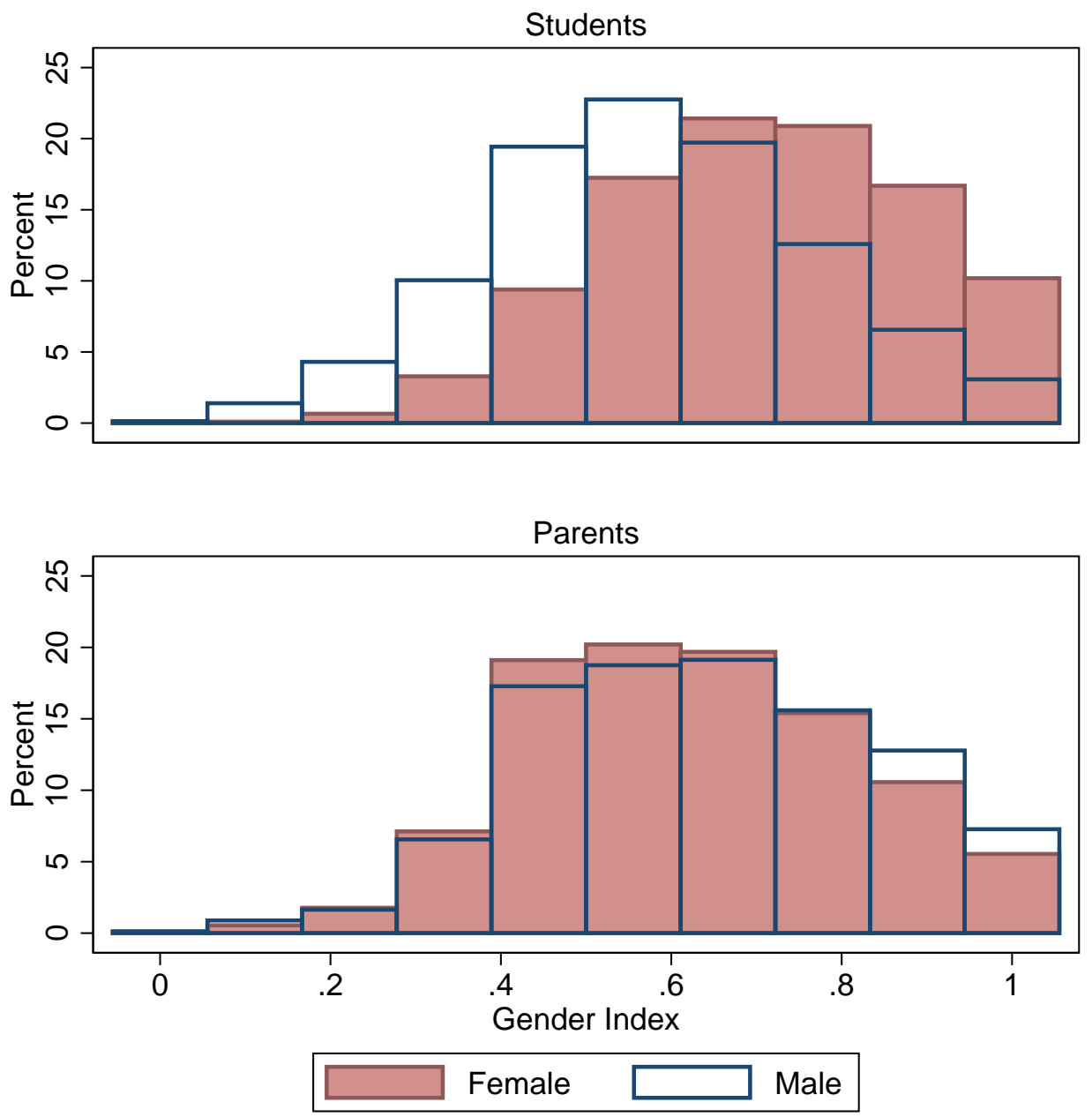

Notes. Surveyed parents and students were asked if they agree with 9 statements regarding gender equality. The gender index is the average value of 9 indicator variables for answering "Agree" or "Strongly agree" ("Disagree" or "Strongly disagree") if the statement was seen as promoting (opposing) gender equality. A higher value corresponds to more gender-equitable attitudes. 
Table 1: Descriptive statistics: Individual and household characteristics

\begin{tabular}{|c|c|c|c|c|}
\hline & Girls & Boys & Mothers & Fathers \\
\hline Age & $\begin{array}{l}11.667 \\
{[1.247]}\end{array}$ & $\begin{array}{c}11.917 \\
{[1.257]}\end{array}$ & $\begin{array}{c}34.951 \\
{[5.595]}\end{array}$ & $\begin{array}{l}40.488 \\
{[6.750]}\end{array}$ \\
\hline 6th Grade & $\begin{array}{c}0.568 \\
{[0.495]}\end{array}$ & $\begin{array}{c}0.508 \\
{[0.500]}\end{array}$ & N/A & N/A \\
\hline Illiterate & $\mathrm{N} / \mathrm{A}$ & $\mathrm{N} / \mathrm{A}$ & $\begin{array}{c}0.390 \\
{[0.488]}\end{array}$ & $\begin{array}{c}0.164 \\
{[0.371]}\end{array}$ \\
\hline Finished primary & $\mathrm{N} / \mathrm{A}$ & N/A & $\begin{array}{c}0.302 \\
{[0.459]}\end{array}$ & $\begin{array}{c}0.274 \\
{[0.446]}\end{array}$ \\
\hline Finished secondary & N/A & N/A & $\begin{array}{c}0.202 \\
{[0.401]}\end{array}$ & $\begin{array}{c}0.270 \\
{[0.444]}\end{array}$ \\
\hline Finished Class 10+ & N/A & N/A & $\begin{array}{c}0.106 \\
{[0.308]}\end{array}$ & $\begin{array}{c}0.292 \\
{[0.455]}\end{array}$ \\
\hline Hindu & $\begin{array}{c}0.945 \\
{[0.228]}\end{array}$ & $\begin{array}{c}0.947 \\
{[0.225]}\end{array}$ & $\begin{array}{c}0.940 \\
{[0.237]}\end{array}$ & $\begin{array}{c}0.953 \\
{[0.212]}\end{array}$ \\
\hline Muslim & $\begin{array}{c}0.053 \\
{[0.223]}\end{array}$ & $\begin{array}{c}0.048 \\
{[0.214]}\end{array}$ & $\begin{array}{c}0.056 \\
{[0.231]}\end{array}$ & $\begin{array}{c}0.043 \\
{[0.203]}\end{array}$ \\
\hline Scheduled caste & $\begin{array}{c}0.174 \\
{[0.339]}\end{array}$ & $\begin{array}{c}0.188 \\
{[0.344]}\end{array}$ & $\begin{array}{c}0.187 \\
{[0.346]}\end{array}$ & $\begin{array}{c}0.172 \\
{[0.335]}\end{array}$ \\
\hline Scheduled tribe & $\begin{array}{c}0.009 \\
{[0.085]}\end{array}$ & $\begin{array}{c}0.011 \\
{[0.094]}\end{array}$ & $\begin{array}{c}0.010 \\
{[0.088]}\end{array}$ & $\begin{array}{c}0.010 \\
{[0.091]}\end{array}$ \\
\hline Number of children & $\begin{array}{c}3.778 \\
{[1.293]}\end{array}$ & $\begin{array}{c}3.263 \\
{[1.227]}\end{array}$ & $\begin{array}{c}3.577 \\
{[1.306]}\end{array}$ & $\begin{array}{c}3.512 \\
{[1.266]}\end{array}$ \\
\hline $\begin{array}{c}\text { Percent sons among } \\
\text { siblings/children }\end{array}$ & $\begin{array}{c}0.563 \\
{[0.299]}\end{array}$ & $\begin{array}{c}0.513 \\
{[0.356]}\end{array}$ & $\begin{array}{c}0.542 \\
{[0.325]}\end{array}$ & $\begin{array}{c}0.540 \\
{[0.328]}\end{array}$ \\
\hline Mother is illiterate & $\begin{array}{c}0.379 \\
{[0.485]}\end{array}$ & $\begin{array}{c}0.405 \\
{[0.491]}\end{array}$ & N/A & $\mathrm{N} / \mathrm{A}$ \\
\hline Father is illiterate & $\begin{array}{c}0.154 \\
{[0.361]}\end{array}$ & $\begin{array}{c}0.177 \\
{[0.382]}\end{array}$ & N/A & N/A \\
\hline Dwelling has flush toilet & $\begin{array}{c}0.165 \\
{[0.371]}\end{array}$ & $\begin{array}{c}0.123 \\
{[0.328]}\end{array}$ & $\begin{array}{c}0.148 \\
{[0.355]}\end{array}$ & $\begin{array}{c}0.145 \\
{[0.352]}\end{array}$ \\
\hline Observations & 3,044 & 2,439 & 3,104 & 2,379 \\
\hline
\end{tabular}

Notes. Table reports variable means and standard deviations. Parents' religion is summarized based on students' answers. Schedule caste and tribe and whether the mother or father is illiterate are summarized based on parents' answers. Percent sons among siblings/children is calculated using siblings for the students (excluding themselves), so it is missing for the $2 \%$ of the sample in one-child families; for parents, it is calculated based on all of their children. 
Table 2: Descriptive statistics: Gender attitudes

\begin{tabular}{lcccc}
\hline & Girls & Boys & Mothers & Fathers \\
\hline Disagree: A woman's most important role & 0.430 & 0.209 & 0.287 & 0.267 \\
is being a good homemaker & {$[0.495]$} & {$[0.407]$} & {$[0.452]$} & {$[0.442]$} \\
Disagree: A man should have the final & 0.513 & 0.328 & 0.412 & 0.439 \\
word about decisions in his home & {$[0.500]$} & {$[0.470]$} & {$[0.492]$} & {$[0.496]$} \\
Disagree: A woman should tolerate & 0.667 & 0.610 & 0.361 & 0.456 \\
violence to keep her family together & {$[0.472]$} & {$[0.488]$} & {$[0.480]$} & {$[0.498]$} \\
Disagree: Wives should be less educated & 0.744 & 0.564 & 0.528 & 0.560 \\
than their husbands & {$[0.436]$} & {$[0.496]$} & {$[0.499]$} & {$[0.497]$} \\
Disagree: Boys should get more & 0.428 & 0.181 & 0.469 & 0.491 \\
opportunities/ resources for education & {$[0.495]$} & {$[0.385]$} & {$[0.499]$} & {$[0.500]$} \\
Men and women should get equal & 0.924 & 0.904 & 0.933 & 0.953 \\
opportunities in all spheres of life & {$[0.265]$} & {$[0.295]$} & {$[0.251]$} & {$[0.211]$} \\
Girls should be allowed to study as far & 0.959 & 0.875 & 0.962 & 0.955 \\
as they want & {$[0.198]$} & {$[0.331]$} & {$[0.192]$} & {$[0.207]$} \\
Daughters should have a similar right to & 0.875 & 0.820 & 0.875 & 0.882 \\
inherited property as sons. & {$[0.331]$} & {$[0.385]$} & {$[0.331]$} & {$[0.323]$} \\
It would be a good idea to elect a woman & 0.810 & 0.692 & 0.805 & 0.779 \\
as the village Sarpanch & {$[0.392]$} & {$[0.462]$} & {$[0.396]$} & {$[0.415]$} \\
Gender index & 0.706 & 0.576 & 0.626 & 0.643 \\
& {$[0.182]$} & {$[0.192]$} & {$[0.192]$} & {$[0.201]$} \\
Weighted gender index & 0.055 & -0.061 & -0.006 & 0.012 \\
& {$[0.176]$} & {$[0.202]$} & {$[0.193]$} & {$[0.200]$} \\
Wishes to complete Class 13+ & 0.536 & 0.625 & N/A & N/A \\
Discusses education goals with parents & {$[0.499]$} & {$[0.484]$} & & \\
Observations & 0.795 & 0.845 & N/A & N/A \\
\hline
\end{tabular}

Notes. Table reports variable means and standard deviations. Surveyed parents and students were asked if they agree with the 9 statements specified, and the variables reported are indicators for answering "Agree" or "Strongly agree" ("Disagree" or "Strongly disagree") if the statement is in favor of (opposed to) gender equality. Gender index is the average of the 9 indicators. For Weighted gender index, the 9 indicators are averaged using weights calculated from the student sample and are rescaled so that its standard deviation matches that of the unweighted index. Wishes to complete Class $13+$ is child wishing to complete grade 13 or higher. The variable equals 0 if child wishes to complete less schooling or answer "Don't know". Discusses education goals with parents is a dummy for answering yes to "Have you ever discussed your education goals with your parents or adult relatives?". 
Table 3: Effect of parental gender attitudes on child gender attitudes

\begin{tabular}{|c|c|c|c|c|c|c|}
\hline & $\begin{array}{c}\text { Student } \\
\text { gender index } \\
\text { (1) }\end{array}$ & $\begin{array}{c}\text { Student } \\
\text { gender index } \\
\text { (2) }\end{array}$ & $\begin{array}{c}\text { Student } \\
\text { gender index } \\
\text { (3) }\end{array}$ & $\begin{array}{c}\text { Student } \\
\text { gender index } \\
\text { (4) }\end{array}$ & $\begin{array}{c}\text { Student } \\
\text { gender index } \\
(5)\end{array}$ & $\begin{array}{c}\text { Student } \\
\text { gender index } \\
\text { (6) }\end{array}$ \\
\hline Classmates' avg gender index & & & & & & $\begin{array}{c}0.127^{* * *} \\
{[0.048]}\end{array}$ \\
\hline Mean of outcome & 0.648 & 0.648 & 0.648 & 0.648 & 0.648 & 0.648 \\
\hline District-grade-gender \& school FEs & No & Yes & Yes & Yes & Yes & Yes \\
\hline Household controls & None & None & Basic & Extended & $\begin{array}{l}\text { Extended + } \\
\text { endogenous }\end{array}$ & Extended \\
\hline Observations & 5483 & 5483 & 5483 & 5483 & 5483 & 5483 \\
\hline
\end{tabular}

Notes. Asterisks denote significance: $* p<.10, * * p<.05, * * * p<.01$. Standard errors are clustered by school-grade-gender. "Basic controls" include:

(student-reported) house is pukka, house has electricity, house has flush toilet, house has non-flush toilet, family owns the house, father is illiterate, father is literate or finished primary school, father finished middle school (Class 8), father works part-time, father works full-time, mother is illiterate, mother is literate or finished primary school, mother finished middle school (Class 8), (parent-reported) scheduled caste, scheduled tribe. "Extended controls" include: (parent-reported) HH has radio, $\mathrm{HH}$ has TV, $\mathrm{HH}$ gets newspaper daily and $\mathrm{HH}$ owns water pump, (student-reported) $\mathrm{HH}$ gets newspaper daily, HH has tap water as well as "basic controls". "Extended + endogenous controls" include: (student-reported) mother works part-time, mother works full-time, number of HH members, number of sisters, and number of brothers as well as "basic controls" and "extended controls". Classmates' avg gender index is the average Gender index of the students of the same gender and age as the respondent in his or her school, and is calculated excluding the respondent's own Gender index. 
Table 4: Effects by parent and child gender

\begin{tabular}{lcccc}
\hline & $\begin{array}{c}\text { Student } \\
\text { gender } \\
\text { index } \\
(1)\end{array}$ & $\begin{array}{c}\text { Student } \\
\text { gender } \\
\text { index } \\
(2)\end{array}$ & $\begin{array}{c}\text { Student } \\
\text { gender } \\
\text { index } \\
(3)\end{array}$ & $\begin{array}{c}\text { Student } \\
\text { gender } \\
\text { index } \\
(4)\end{array}$ \\
\hline Parent gender index & $0.146^{* * *}$ & $0.112^{* * *}$ & $0.174^{* * *}$ & $0.157^{* * *}$ \\
& {$[0.014]$} & {$[0.021]$} & {$[0.020]$} & {$[0.029]$} \\
Mother*Parent gender index & & $0.063^{* *}$ & & 0.034 \\
& & {$[0.027]$} & & {$[0.040]$} \\
Girl*Parent gender index & & & $-0.051^{*}$ & $-0.088^{* *}$ \\
& & & {$[0.028]$} & {$[0.040]$} \\
Mother*Girl*Parent gender index & & & & 0.064 \\
& & & & {$[0.055]$} \\
\hline DGG \& school FEs & Yes & Yes & Yes & Yes \\
Extended HH controls & Yes & Yes & Yes & Yes \\
No effect on girls & & & 0.000 & \\
Mom/girl=Mom/boy & & & & 0.528 \\
Dad has no effect on girls & & & & 0.015 \\
Observations & 5,483 & 5,483 & 5,483 & 5,483 \\
\hline
\end{tabular}

Notes. Asterisks denote significance: $* p<.10, * * p<.05, * * * p<.01$. Standard errors are clustered by school-grade-gender. $D G G$ stands for

District*Grade*Gender fixed effects. Columns 2 and 4 include but do not report the main effect for Mother. Column 3 also includes Propensity score to be a boy and its interaction with Parent gender index. Propensity score to be a boy is generated by running a probit regression of being a boy on household characteristics using the 5,483 sample children. The covariates are the same variables included in "extended HH controls". The variable is demeaned and missing values are replaced with the sample mean; flags for missing values are included in the propensity score regression. Column 4 includes Propensity score to be a boy and its interaction with Parent gender index, Mother and Mother*Parent gender index. "No effect on girls" reports the p-value of testing Girl*Parent gender index + Parent gender index $=0$. "Mom/girl=Mom/boy" reports the p-value of testing Mother*Girl*Parent gender index + Girl*Parent gender index $=0$. "Dad has no effect on girls" reports the p-value of testing Girl*Parent gender index + Parent gender index $=0$. 
Table 5: Effect of parent gender attitudes on educational aspirations

\begin{tabular}{|c|c|c|c|c|c|c|}
\hline & $\begin{array}{l}\text { Wishes to } \\
\text { complete } \\
\text { Class } 13+ \\
\text { (1) }\end{array}$ & $\begin{array}{l}\text { Wishes to } \\
\text { complete } \\
\text { Class } 13+ \\
\text { (2) }\end{array}$ & $\begin{array}{l}\text { Wishes to } \\
\text { complete } \\
\text { Class } 13+ \\
\text { (3) }\end{array}$ & $\begin{array}{c}\text { Discusses } \\
\text { education } \\
\text { goals with } \\
\text { parents } \\
\text { (4) }\end{array}$ & $\begin{array}{c}\text { Discusses } \\
\text { education } \\
\text { goals with } \\
\text { parents } \\
\text { (5) }\end{array}$ & $\begin{array}{c}\text { Discusses } \\
\text { education } \\
\text { goals with } \\
\text { parents } \\
\text { (6) }\end{array}$ \\
\hline Parent gender index & $\begin{array}{l}0.072^{* *} \\
{[0.035]}\end{array}$ & $\begin{array}{c}-0.016 \\
{[0.053]}\end{array}$ & $\begin{array}{l}0.165^{* *} \\
{[0.076]}\end{array}$ & $\begin{array}{c}0.013 \\
{[0.028]}\end{array}$ & $\begin{array}{c}-0.040 \\
{[0.040]}\end{array}$ & $\begin{array}{c}0.059 \\
{[0.059]}\end{array}$ \\
\hline Girl*Parent gender index & & $\begin{array}{l}0.160^{* *} \\
{[0.073]}\end{array}$ & & & $\begin{array}{c}0.094^{*} \\
{[0.057]}\end{array}$ & \\
\hline Mother*Parent gender index & & & $\begin{array}{c}-0.062 \\
{[0.099]}\end{array}$ & & & $\begin{array}{c}0.024 \\
{[0.080]}\end{array}$ \\
\hline Controls for prop. to be boy & No & Yes & No & No & Yes & No \\
\hline DGG \& school FEs & Yes & Yes & Yes & Yes & Yes & Yes \\
\hline Extended HH controls & Yes & Yes & Yes & Yes & Yes & Yes \\
\hline Sample & All & All & Girls & All & All & Girls \\
\hline No effect on girls & & 0.003 & & & 0.179 & \\
\hline Observations & 5,480 & 5,480 & 3,042 & 5,483 & 5,483 & 3,044 \\
\hline
\end{tabular}

Notes. Asterisks denote significance: $* p<.10, * * p<.05$, *** $p<.01$. Standard errors are clustered by school-grade-gender. Columns 3 and 6 include but do not report the main effect for Mother. "Controls for prop. to be boy" indicates if Propensity score to be a boy and its interactions are included. DGG stands for District*Grade*Gender fixed effects. Wishes to complete Class $13+$ is the child's response to how much schooling he or she wished to obtain and equals 0 if he or she wishes to complete less than 13 years or answered "don't know". Discusses education goals with parents is a dummy for answering yes to "Have you ever discussed your education goals with your parents or adult relatives?". 


\section{Appendix Table 1: Gender attitude differences by parent and child gender}

\begin{tabular}{lcccc}
\hline & $\begin{array}{c}\text { Parent gender } \\
\text { index } \\
(1)\end{array}$ & $\begin{array}{c}\text { Student } \\
\text { gender index } \\
(2)\end{array}$ & $\begin{array}{c}\text { Student } \\
\text { gender index } \\
(3)\end{array}$ & $\begin{array}{c}\text { Student } \\
\text { gender index } \\
(4)\end{array}$ \\
\hline Mother & $-0.018^{* * *}$ & & & \\
Girl & {$[0.005]$} & & & \\
& & $0.114^{* * *}$ & $0.119^{* * *}$ & $0.114^{* * *}$ \\
Propensity score to be a boy & & {$[0.008]$} & {$[0.008]$} & {$[0.008]$} \\
& & & & $-0.078^{* * *}$ \\
District-Grade \& school FEs & Yes & Yes & Yes & Yes \\
Extended HH controls & Yes & Yes & No & No \\
Observations & 5,483 & 5,483 & 5,483 & 5,483 \\
\hline
\end{tabular}

Notes. Asterisks denote significance: $* p<.10,{ }^{* *} p<.05, * * * p<.01$. Standard errors are clustered by school-grade-gender. Propensity score to be a boy is generated by running a probit regression of being a boy on household characteristics using the 5,483 sample children. The covariates are the same variables included in "extended HH controls". The variable is demeaned and missing values are replaced with the sample mean; flags for missing values are included in the propensity score regression. Surveyed parents and students were asked if they agree with 9 statements about gender equality, and we created dummies for answering "Agree" or "Strongly agree" ("Disagree" or "Strongly disagree") if the statement was in favor of (opposed to) gender equality. Gender index is the average of the 9 dummies. 


\section{Appendix Table 2: Disaggregated results by gender attitude question}

\begin{tabular}{|c|c|c|c|c|c|c|c|c|c|}
\hline & $\begin{array}{l}\text { Disagree: } \\
\text { A woman's } \\
\text { most impt } \\
\text { role is } \\
\text { being a } \\
\text { good } \\
\text { home- } \\
\text { maker } \\
(1)\end{array}$ & $\begin{array}{l}\text { Disagree: } \\
\text { A man } \\
\text { should } \\
\text { have final } \\
\text { word about } \\
\text { decisions } \\
\text { in home } \\
\text { (2) }\end{array}$ & $\begin{array}{c}\text { Disagree: } \\
\text { A woman } \\
\text { should } \\
\text { tolerate } \\
\text { violence to } \\
\text { keep } \\
\text { family } \\
\text { together } \\
(3)\end{array}$ & $\begin{array}{l}\text { Disagree: } \\
\text { Wives } \\
\text { should be } \\
\text { less } \\
\text { educated } \\
\text { than their } \\
\text { husbands } \\
\text { (4) }\end{array}$ & $\begin{array}{l}\text { Disagree: } \\
\text { Boys } \\
\text { should get } \\
\text { more op- } \\
\text { portunities } \\
\text { for } \\
\text { education } \\
\text { than girls } \\
\quad(5)\end{array}$ & $\begin{array}{c}\text { Men \& } \\
\text { women } \\
\text { should get } \\
\text { equal op- } \\
\text { portunities } \\
\text { in all } \\
\text { spheres } \\
\text { (6) }\end{array}$ & $\begin{array}{c}\text { Girls } \\
\text { should be } \\
\text { allowed to } \\
\text { study as far } \\
\text { as they } \\
\text { want } \\
\text { (7) }\end{array}$ & $\begin{array}{l}\text { Daughters } \\
\text { should } \\
\text { have } \\
\text { similar } \\
\text { right to } \\
\text { inherited } \\
\text { property as } \\
\text { sons } \\
(8)\end{array}$ & $\begin{array}{l}\text { It would be } \\
\text { a good idea } \\
\text { to elect a } \\
\text { woman as } \\
\text { the village } \\
\text { Sarpanch } \\
\text { (9) }\end{array}$ \\
\hline Parent's attitude & $\begin{array}{c}0.123^{* * *} \\
{[0.015]}\end{array}$ & $\begin{array}{c}0.115^{\text {*** }} \\
{[0.014]}\end{array}$ & $\begin{array}{c}0.092^{* * *} \\
{[0.014]}\end{array}$ & $\begin{array}{c}0.074^{* * *} \\
{[0.013]}\end{array}$ & $\begin{array}{c}0.120^{* * *} \\
{[0.013]}\end{array}$ & $\begin{array}{c}0.033^{*} \\
{[0.020]}\end{array}$ & $\begin{array}{c}0.028 \\
{[0.022]}\end{array}$ & $\begin{array}{l}0.035^{* *} \\
{[0.017]} \\
\end{array}$ & $\begin{array}{c}0.044^{* * *} \\
{[0.016]}\end{array}$ \\
\hline Student attitude mean & 0.332 & 0.431 & 0.641 & 0.664 & 0.318 & 0.915 & 0.921 & 0.850 & 0.758 \\
\hline DGG \& school FEs & Yes & Yes & Yes & Yes & Yes & Yes & Yes & Yes & Yes \\
\hline Extended HH controls & Yes & Yes & Yes & Yes & Yes & Yes & Yes & Yes & Yes \\
\hline Observations & 5,483 & 5,483 & 5,483 & 5,483 & 5,483 & 5,483 & 5,483 & 5,483 & 5,483 \\
\hline
\end{tabular}

Notes. Asterisks denote significance: $* p<.10,{ }^{*} p<.05, * * * p<.01$. Standard errors are clustered by school-grade-gender. $D G G$ stands for District*Grade*Gender fixed effects. 


\section{Appendix Table 3: Instrumental variables results to address measurement error}

\begin{tabular}{|c|c|c|c|c|c|c|c|c|c|c|}
\hline \multirow{2}{*}{$\begin{array}{l}\text { Outcome: } \\
\text { Parent attitude: }\end{array}$} & \multicolumn{9}{|c|}{ Student gender index } & \multirow[b]{2}{*}{$\begin{array}{c}\text { Average of } \\
\text { coefficients } \\
(1-9) \\
(10)\end{array}$} \\
\hline & $\begin{array}{l}\text { Disagree: } \\
\text { Woman's } \\
\text { most impt } \\
\text { role is } \\
\text { being good } \\
\text { homemaker } \\
\text { (1) }\end{array}$ & $\begin{array}{c}\text { Disagree: } \\
\text { Man should } \\
\text { have final } \\
\text { word about } \\
\text { decisions at } \\
\text { home } \\
\text { (2) }\end{array}$ & $\begin{array}{c}\text { Disagree: } \\
\text { Woman } \\
\text { should } \\
\text { tolerate } \\
\text { violence to } \\
\text { keep family } \\
\text { together } \\
\text { (3) }\end{array}$ & $\begin{array}{l}\text { Disagree: } \\
\text { Wives } \\
\text { should be } \\
\text { less } \\
\text { educated } \\
\text { than their } \\
\text { husbands } \\
\text { (4) }\end{array}$ & $\begin{array}{l}\text { Disagree: } \\
\text { Boys } \\
\text { should get } \\
\text { more opp. } \\
\text { for educ } \\
\text { than girls } \\
\text { (5) }\end{array}$ & $\begin{array}{l}\text { Men \& } \\
\text { women } \\
\text { should get } \\
\text { equal opp. } \\
\text { in all } \\
\text { spheres of } \\
\text { life } \\
\text { (6) }\end{array}$ & $\begin{array}{c}\text { Girls } \\
\text { should be } \\
\text { allowed to } \\
\text { study as far } \\
\text { as they } \\
\text { want } \\
\text { (7) }\end{array}$ & $\begin{array}{l}\text { Daughters } \\
\text { should have } \\
\text { a similar } \\
\text { right to } \\
\text { inherited } \\
\text { property as } \\
\text { sons } \\
\text { (8) }\end{array}$ & $\begin{array}{l}\text { It would be } \\
\text { a good idea } \\
\text { to elect a } \\
\text { woman as } \\
\text { the village } \\
\text { Sarpanch } \\
\text { (9) }\end{array}$ & \\
\hline Parent attitude & $\begin{array}{c}0.146^{* * *} \\
{[0.016]}\end{array}$ & $\begin{array}{c}0.127^{* * *} \\
{[0.012]}\end{array}$ & $\begin{array}{c}0.215^{* * *} \\
{[0.026]}\end{array}$ & $\begin{array}{c}0.150^{* * *} \\
{[0.014]}\end{array}$ & $\begin{array}{c}0.126^{* * *} \\
{[0.015]}\end{array}$ & $\begin{array}{c}0.372^{* * *} \\
{[0.085]}\end{array}$ & $\begin{array}{c}0.402^{* * *} \\
{[0.071]}\end{array}$ & $\begin{array}{c}0.243^{* * *} \\
{[0.042]}\end{array}$ & $\begin{array}{c}0.245^{* * *} \\
{[0.042]}\end{array}$ & $\begin{array}{c}0.225 \\
{[0.036]}\end{array}$ \\
\hline DGG \& school FEs & Yes & Yes & Yes & Yes & Yes & Yes & Yes & Yes & Yes & \\
\hline Ext. HH controls & Yes & Yes & Yes & Yes & Yes & Yes & Yes & Yes & Yes & \\
\hline Observations & 5,483 & 5,483 & 5,483 & 5,483 & 5,483 & 5,483 & 5,483 & 5,483 & 5,483 & 5,483 \\
\hline
\end{tabular}

Notes. Asterisks denote significance: $* p<.10, * * p<.05, * * * p<.01$. Standard errors are clustered by school-grade-gender. $D G G$ stands for District*Grade*Gender fixed effects. The endogenous regressor (Parent attitude) in each column is instrumented by the remaining 8 components of the parents' Gender index. First-stage results are reported in the following table. The last column is not a regression but an average of the coefficients reported in columns 1-9. The standard error is also an average of the standard errors from columns 1-9. 
Appendix Table 4: Instrumental variables: First stage results

\begin{tabular}{|c|c|c|c|c|c|c|c|c|c|}
\hline Parent attitude: & $\begin{array}{l}\text { Disagree: } \\
\text { Woman's } \\
\text { most impt } \\
\text { role is } \\
\text { being good } \\
\text { homemaker } \\
\text { (1) }\end{array}$ & $\begin{array}{l}\text { Disagree: } \\
\text { Man should } \\
\text { have final } \\
\text { word about } \\
\text { decisions at } \\
\text { home } \\
\text { (2) }\end{array}$ & $\begin{array}{l}\text { Disagree: } \\
\text { Woman } \\
\text { should } \\
\text { tolerate } \\
\text { violence to } \\
\text { keep family } \\
\text { together } \\
\text { (3) }\end{array}$ & $\begin{array}{l}\text { Disagree: } \\
\text { Wives } \\
\text { should be } \\
\text { less } \\
\text { educated } \\
\text { than their } \\
\text { husbands } \\
\text { (4) }\end{array}$ & $\begin{array}{l}\text { Disagree: } \\
\text { Boys } \\
\text { should get } \\
\text { more opp. } \\
\text { for educ } \\
\text { than girls } \\
\text { (5) }\end{array}$ & $\begin{array}{c}\text { Men \& } \\
\text { women } \\
\text { should get } \\
\text { equal opp. } \\
\text { in all } \\
\text { spheres of } \\
\text { life } \\
(6)\end{array}$ & $\begin{array}{c}\text { Girls } \\
\text { should be } \\
\text { allowed to } \\
\text { study as far } \\
\text { as they } \\
\text { want } \\
\text { (7) }\end{array}$ & $\begin{array}{l}\text { Daughters } \\
\text { should have } \\
\text { a similar } \\
\text { right to } \\
\text { inherited } \\
\text { property as } \\
\text { sons } \\
(8)\end{array}$ & $\begin{array}{l}\text { It would be } \\
\text { a good idea } \\
\text { to elect a } \\
\text { woman as } \\
\text { the village } \\
\text { Sarpanch } \\
\text { (9) }\end{array}$ \\
\hline $\begin{array}{l}\text { Disagree: Woman's most impt role is } \\
\text { being good homemaker }\end{array}$ & & $\begin{array}{c}0.286^{* * *} \\
{[0.016]}\end{array}$ & $\begin{array}{c}0.145^{* * *} \\
{[0.017]}\end{array}$ & $\begin{array}{l}0.129^{* * *} \\
{[0.016]}\end{array}$ & $\begin{array}{c}0.073^{* * *} \\
{[0.017]}\end{array}$ & $\begin{array}{l}-0.019^{* *} \\
{[0.008]}\end{array}$ & $\begin{array}{c}0.021^{* * *} \\
{[0.006]}\end{array}$ & $\begin{array}{c}0.007 \\
{[0.011]}\end{array}$ & $\begin{array}{c}0.036^{* * *} \\
{[0.013]}\end{array}$ \\
\hline $\begin{array}{l}\text { Disagree: Man should have final word } \\
\text { about decisions at home }\end{array}$ & $\begin{array}{l}0.239^{* * *} \\
{[0.014]}\end{array}$ & & $\begin{array}{c}0.098^{* * *} \\
{[0.016]}\end{array}$ & $\begin{array}{c}0.138^{* * *} \\
{[0.016]}\end{array}$ & $\begin{array}{c}0.194^{* * *} \\
{[0.016]}\end{array}$ & $\begin{array}{c}0.029^{* * *} \\
{[0.008]}\end{array}$ & $\begin{array}{l}-0.009 \\
{[0.007]}\end{array}$ & $\begin{array}{c}0.004 \\
{[0.010]}\end{array}$ & $\begin{array}{c}0.046^{* * *} \\
{[0.013]}\end{array}$ \\
\hline $\begin{array}{l}\text { Disagree: Woman tolerate violence to } \\
\text { keep family together }\end{array}$ & $\begin{array}{l}0.104^{* * *} \\
{[0.012]}\end{array}$ & $\begin{array}{c}0.084^{* * *} \\
{[0.014]}\end{array}$ & & $\begin{array}{l}0.076^{* * *} \\
{[0.014]}\end{array}$ & $\begin{array}{l}-0.003 \\
{[0.014]}\end{array}$ & $\begin{array}{c}0.006 \\
{[0.007]}\end{array}$ & $\begin{array}{c}0.006 \\
{[0.006]}\end{array}$ & $\begin{array}{l}0.018^{*} \\
{[0.010]}\end{array}$ & $\begin{array}{c}0.004 \\
{[0.012]}\end{array}$ \\
\hline $\begin{array}{l}\text { Disagree: Wives should be less educated } \\
\text { than their husbands }\end{array}$ & $\begin{array}{c}0.100^{* * *} \\
{[0.012]}\end{array}$ & $\begin{array}{c}0.128^{* * *} \\
{[0.015]}\end{array}$ & $\begin{array}{c}0.082^{* * *} \\
{[0.015]}\end{array}$ & & $\begin{array}{c}0.214^{* * *} \\
{[0.015]}\end{array}$ & $\begin{array}{c}0.004 \\
{[0.008]}\end{array}$ & $\begin{array}{l}0.016^{* *} \\
{[0.006]}\end{array}$ & $\begin{array}{c}0.017 \\
{[0.010]}\end{array}$ & $\begin{array}{c}0.035^{* * *} \\
{[0.013]}\end{array}$ \\
\hline $\begin{array}{l}\text { Disagree: Boys should get more opp. for } \\
\text { educ than girls }\end{array}$ & $\begin{array}{c}0.056^{* * *} \\
{[0.013]}\end{array}$ & $\begin{array}{l}0.179^{* * *} \\
{[0.015]}\end{array}$ & $\begin{array}{l}-0.003 \\
{[0.015]}\end{array}$ & $\begin{array}{l}0.214^{* * *} \\
{[0.015]}\end{array}$ & & $\begin{array}{c}0.002 \\
{[0.007]}\end{array}$ & $\begin{array}{l}0.026^{* * *} \\
{[0.006]}\end{array}$ & $\begin{array}{l}0.040^{* * *} \\
{[0.011]}\end{array}$ & $\begin{array}{l}-0.002 \\
{[0.012]}\end{array}$ \\
\hline $\begin{array}{l}\text { Men \& women should get equal opp. in } \\
\text { all spheres of life }\end{array}$ & $\begin{array}{c}-0.054^{* *} \\
{[0.024]}\end{array}$ & $\begin{array}{c}0.098^{* * *} \\
{[0.027]}\end{array}$ & $\begin{array}{c}0.025 \\
{[0.028]}\end{array}$ & $\begin{array}{c}0.014 \\
{[0.028]}\end{array}$ & $\begin{array}{c}0.008 \\
{[0.025]}\end{array}$ & & $\begin{array}{c}0.080^{* * *} \\
{[0.019]}\end{array}$ & $\begin{array}{l}0.085^{* * *} \\
{[0.022]}\end{array}$ & $\begin{array}{l}0.093^{* * *} \\
{[0.027]}\end{array}$ \\
\hline $\begin{array}{l}\text { Girls should be allowed to study as far as } \\
\text { they want }\end{array}$ & $\begin{array}{c}0.086^{* * *} \\
{[0.023]}\end{array}$ & $\begin{array}{l}-0.044 \\
{[0.033]}\end{array}$ & $\begin{array}{c}0.035 \\
{[0.032]}\end{array}$ & $\begin{array}{l}0.086^{* *} \\
{[0.034]}\end{array}$ & $\begin{array}{l}0.139^{* * *} \\
{[0.029]}\end{array}$ & $\begin{array}{l}0.116^{* * *} \\
{[0.027]}\end{array}$ & & $\begin{array}{c}0.215^{* * *} \\
{[0.034]}\end{array}$ & $\begin{array}{c}0.147^{* * *} \\
{[0.033]}\end{array}$ \\
\hline $\begin{array}{l}\text { Daughters should have a similar right to } \\
\text { property as sons }\end{array}$ & $\begin{array}{c}0.011 \\
{[0.017]}\end{array}$ & $\begin{array}{c}0.007 \\
{[0.018]}\end{array}$ & $\begin{array}{l}0.037^{*} \\
{[0.021]}\end{array}$ & $\begin{array}{c}0.032 \\
{[0.020]}\end{array}$ & $\begin{array}{c}0.078^{* * *} \\
{[0.021]}\end{array}$ & $\begin{array}{c}0.045^{* * *} \\
{[0.012]}\end{array}$ & $\begin{array}{c}0.079^{* * *} \\
{[0.013]}\end{array}$ & & $\begin{array}{c}0.106^{* * *} \\
{[0.020]}\end{array}$ \\
\hline $\begin{array}{l}\text { It would be good idea to elect woman as } \\
\text { the village Sarpanch }\end{array}$ & $\begin{array}{c}0.036^{* * *} \\
{[0.013]}\end{array}$ & $\begin{array}{c}0.055^{* * *} \\
{[0.015]}\end{array}$ & $\begin{array}{c}0.006 \\
{[0.017]}\end{array}$ & $\begin{array}{l}0.045^{* * *} \\
{[0.016]}\end{array}$ & $\begin{array}{l}-0.003 \\
{[0.016]}\end{array}$ & $\begin{array}{l}0.033^{* * *} \\
{[0.009]}\end{array}$ & $\begin{array}{c}0.036^{* * *} \\
{[0.008]}\end{array}$ & $\begin{array}{l}0.070^{* * *} \\
{[0.013]}\end{array}$ & \\
\hline $\begin{array}{l}\text { Joint F-statistic } \\
\text { Observations }\end{array}$ & $\begin{array}{c}104.86 \\
5,483\end{array}$ & $\begin{array}{c}166.37 \\
5,483\end{array}$ & $\begin{array}{l}35.94 \\
5,483\end{array}$ & $\begin{array}{c}115.94 \\
5,483\end{array}$ & $\begin{array}{l}88.48 \\
5,483\end{array}$ & $\begin{array}{c}8.38 \\
5,483\end{array}$ & $\begin{array}{l}15.10 \\
5,483\end{array}$ & $\begin{array}{l}17.24 \\
5,483\end{array}$ & $\begin{array}{l}18.39 \\
5,483\end{array}$ \\
\hline
\end{tabular}

Notes. Asterisks denote significance: $* p<.10, * * p<.05, * * * p<.01$. Standard errors are clustered by school-grade-gender. First-stage results are reported. In each column, the instruments are the remaining 8 components of the parents' Gender index. "Joint F-statistic" tests that the 8 instruments are jointly equal to 0. 
Appendix Table 5: Alternative specifications: Weighted gender index and ordered logit

\begin{tabular}{|c|c|c|c|c|c|c|c|c|}
\hline & \multicolumn{4}{|c|}{ Weighted gender index } & \multicolumn{4}{|c|}{ Ordered logit } \\
\hline & $\begin{array}{l}\text { Student } \\
\text { gender } \\
\text { index } \\
(1)\end{array}$ & $\begin{array}{c}\text { Student } \\
\text { gender } \\
\text { index } \\
(2)\end{array}$ & $\begin{array}{l}\text { Student } \\
\text { gender } \\
\text { index } \\
(3)\end{array}$ & $\begin{array}{c}\text { Student } \\
\text { gender } \\
\text { index } \\
(4)\end{array}$ & $\begin{array}{c}\text { Student } \\
\text { gender } \\
\text { index } \\
(5)\end{array}$ & $\begin{array}{c}\text { Student } \\
\text { gender } \\
\text { index } \\
(6)\end{array}$ & $\begin{array}{l}\text { Student } \\
\text { gender } \\
\text { index } \\
(7)\end{array}$ & $\begin{array}{c}\text { Student } \\
\text { gender } \\
\text { index } \\
(8)\end{array}$ \\
\hline Parent gender index & $\begin{array}{c}0.110^{* * *} \\
{[0.015]}\end{array}$ & $\begin{array}{c}0.079^{* * *} \\
{[0.021]}\end{array}$ & $\begin{array}{c}0.125^{* * *} \\
{[0.022]}\end{array}$ & $\begin{array}{c}0.104^{* * *} \\
{[0.030]}\end{array}$ & $\begin{array}{c}1.495^{* * *} \\
{[0.151]}\end{array}$ & $\begin{array}{c}1.174^{* * *} \\
{[0.223]}\end{array}$ & $\begin{array}{c}1.780^{* * *} \\
{[0.213]}\end{array}$ & $\begin{array}{l}1.610^{* * *} \\
{[0.307]}\end{array}$ \\
\hline Girl*Parent gender index & & & $\begin{array}{c}-0.028 \\
{[0.029]}\end{array}$ & $\begin{array}{c}-0.053 \\
{[0.041]}\end{array}$ & & & $\begin{array}{l}-0.507^{*} \\
{[0.288]}\end{array}$ & $\begin{array}{c}-0.857^{* *} \\
{[0.429]}\end{array}$ \\
\hline Mother*Girl*Parent gender index & & & & $\begin{array}{c}0.039 \\
{[0.058]}\end{array}$ & & & & $\begin{array}{c}0.570 \\
{[0.587]}\end{array}$ \\
\hline Mom/girl=Mom/boy & & & & 0.731 & & & & 0.469 \\
\hline Dad has no effect on girls & & & & 0.074 & & & & 0.016 \\
\hline Observations & 5,483 & 5,483 & 5,483 & 5,483 & 5,483 & 5,483 & 5,483 & 5,483 \\
\hline
\end{tabular}

Notes. Asterisks denote significance: $* p<.10, * * p<.05, * * * p<.01$. Standard errors are clustered by school-grade-gender. Columns $2,4,6$, and 8 include but do not report the main effect for Mother. In columns 1-4, both parent and student Gender indices are optimally weighted using weights calculated from the student sample. Columns 5 to 8 use the unweighted average. Columns 3 and 7 also include Propensity score to be a boy and its interaction with Parent gender index.

Columns 4 and 8 include Propensity score to be a boy and its interaction with Parent gender index, Mother and Mother*Parent gender index. DGG stands for District*Grade*Gender fixed effects. "No effect on girls" reports the p-value of testing Girl*Parent gender index + Parent gender index $=0$.

"Mom/girl=Mom/boy" reports the p-value of testing Mother*Girl*Parent gender index + Girl*Parent gender index=0. "Dad has no effect on girls" reports the p-value of testing Girl*Parent gender index + Parent gender index $=0$. 